\title{
The Influence of Strategic Leadership, Intrapreneurship Orientation, and University Support on the Commercialization Capability of Academics in Higher Education at USU
}

\author{
Inneke Qamariah $^{1^{*}}$,Yasmin Chairunisa Muchtar ${ }^{2}$
}

\author{
${ }^{1}$ University Sumatera Utara \\ ${ }^{2}$ University Sumatera Utara \\ *Corresponding author.Email: innekelubis@gmail.com
}

\begin{abstract}
This study has an objective to to analyze the influence of Intrapreneurship, Strategic Leadership, University Support on Commercialization Capability of Academics in Higher Education at USU. The sample in this study is an active lecturer at the Universitas Sumatera Utara who has conducted research in 83 sample. The method this research uses descriptive quantitative research. This study uses Multiple Linear Regression Analysis with the results of Intrapreneurship having a positive and significant effect on the Commercialization Capability of Academics, Strategic Leadership has a negative and significant effect on the Commercialization Capability of Academics and University Support has a positive and insignificant effect on Commercialization.
\end{abstract}

Keywords: Intrapreneurship, Strategic Leadership, University Support, Commercialization

\section{INTRODUCTION}

Academic commercialization capabilities such as intellectual property rights, patents, scientific publications are the result of research that is useful for teaching students. The Tri Dharma of Higher Education is an important factor at University level. The results of higher education academics research show how the university can support a transformation from entrepreneurial-based institutions so that the experience of making research can encourage the commercialization capabilities of academics in higher education.

Rapid and drastic environmental changes have forced leaders to have more than usual strategic abilities and leadership behavior in order to be able to anticipate all of these changes. Ireland and Hitt (1999) add that the results of Strategic Leadership will be able to help organizations achieve superior performance compared to other competitors. Strategic leadership is a process of forming a vision for the future, which then communicates to subordinates with the aim of motivating and stimulating them to engage in exchange of supportive strategies with colleagues and subordinates (Elenkov et al, 2005). Employee entrepreneurial activity can be said to be an indicator of communication and intrapreneurial activity in an organization.

This entrepreneurial university is closely linked to industrial, social and governmental needs (Etzkowitz
2016) and it is recommended for diversifying funding sources (Slaughter and Leslie, 2001; Tijssen, 2006). Another reason, is the growth of an diminished willingness to provide public funding to universities due to a lack of government resources and an increase in students.

\section{PROBLEM IDENTIFICATION}

Do Strategic Leadership, Intrapreneurship Orientation and University Support affect the Commercialization Capability of Academics at Universitas Sumatera Utara?

\section{LITERATURE REVIEW}

\subsection{Strategic direction}

Rowe (2001) adds that Strategic direction is the ability to influence others to be able to make decisions in daily activities Determine strategic direction will improve the survival of the organization in the long term and simultaneously. According to Sosik, et al. (2005) there are five indicators of Strategic Leadership, namely: (1) Establish a strategy direction, 2) Find and maintain distinctive key skills, and 3) Develop human resources. (4) Maintain a positive corporate culture. (5) Emphasize and balance ethical practices Establish well-organized management consolidated. 


\subsection{Intrapreneurship}

Entrepreneurship, commonly referred to as entrepreneurship (EC), several studies have shown that it has the ability to increase organizational performance (Bolton and Lane, 2012; Bosma, Stam and Wennekers, 2012). Brigi and Umihani (Brigi and Umihani, 2015). EC is frequently linked with a top-down strategy to supporting entrepreneurship, whereas entrepreneurship is more often a bottom-up process, with people initiating and initiating their own ventures. (Nyström, 2012).

Internal conduct can be described as doing business in established organizations of various sizes for the sake of this study. (Antončič and Hisrich, 2003; Blundell and Lockett, 2011; Pinchot, 1985). .

Therefore, entrepreneurship is a practice of entrepreneurship in today's organizations, characterized by behavioral intention derived from habits (Coulthard and Loos, 2007; Kuratko and Hodgetts, 1995).

\subsection{Strategic Leadership}

The commercialization of knowledge is becoming increasingly important for universities around the world. Concepts and theories such as university entrepreneurship (Etzkowitz, 2003).

\section{CONCEPTUAL FRAMEWORK}

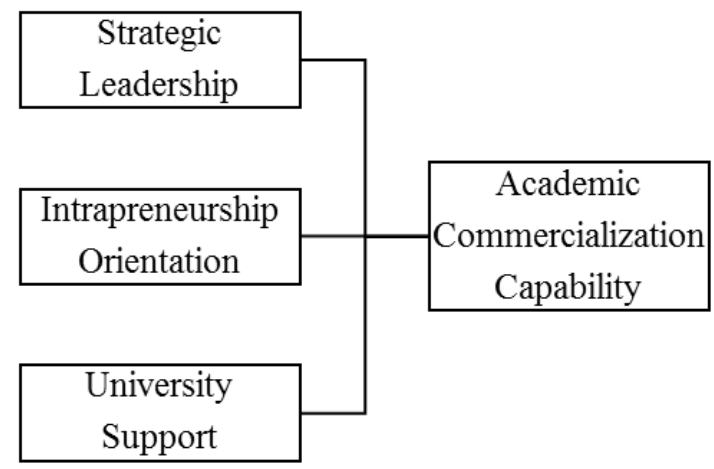

Figure 1 Conceptual Framework

\section{HYPOTHESIS}

H1: Strategic Leadership has a positive and significant effect on Academic Commercialization Capabilities

H2: Entrepreneurship Orientation has a positive and significant effect on Academic Commercialization Capabilities

H3: University Support has a positive and significant effect on Academic Commercialization Capabilities

\section{RESEARCH METHODOLOGY}

\subsection{Population}

The population of this study is Universitas Sumatera Utara who had conducted Talenta research of 504 research titles.

\subsection{Sample}

The sampling technique used is random sampling. The primary data collection is conducted by distributing questionnaires directly or using email. The number of respondents in this study was 83 samples.

\section{DATA COLLECTION METHODS}

In this study, researchers used two methods: (1) Distribution of questionnaires. (2) Examine the document. Desk surveys are a method of collecting data through books, magazines, and the Internet and are used as reference material for researchers.

\section{RESULT AND DISCUSSION}

Table 1. R-Square

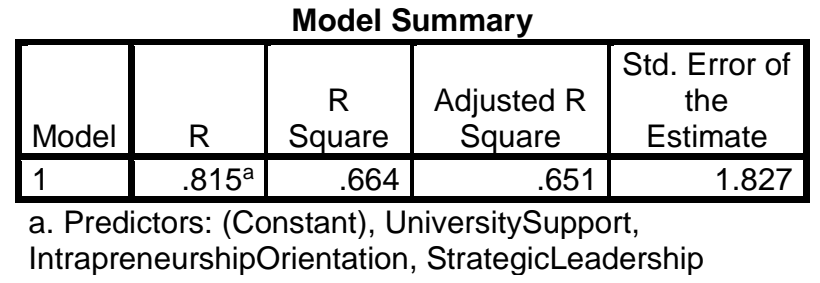

The aforementioned table shows that the adjusted RSquare value is 0,651 or $65.1 \%$. This shows that several independent variables such as Strategic Leadership, Intrapreneurship Orientation and University Support have succeed to explain the Academic Commercialization Capability. And the remaining $34.9 \%$ will be explained by other factors not mentioned in this study.

Table 2. $F_{\text {test }}$

\section{ANOVA $^{\mathrm{a}}$}

\begin{tabular}{|l|r|r|r|r|r|}
\hline \multicolumn{1}{|l|}{ Model } & $\begin{array}{c}\text { Sum of } \\
\text { Squares }\end{array}$ & df & $\begin{array}{c}\text { Mean } \\
\text { Square }\end{array}$ & F & Sig. \\
\hline 1 Regression & 520.442 & 3 & 173.481 & 51.957 & $.000^{\mathrm{b}}$ \\
Residual & 263.775 & 79 & 3.339 & & \\
\multicolumn{1}{|c|}{ Total } & 784.217 & 82 & & & \\
\hline
\end{tabular}

a. Dependent Variable: Commercialization Capability

b. Predictors: (Constant), University Support, Intrapreneurship Orientation, Strategic Leadership

As visible withinside the desk above, it's miles acknowledged that the quantity samples is 83 
respondents, and the calculated cost is 51,957> F table (2.71) at $\alpha=0.05$ and a importance fee of $0.00<0.05$. This variable $X$, namely Strategic Leadership, Table 3. $T_{\text {test }}$ Coefficients Regression Table
Intrapreneurship Orientation and University Support, have a simultaneous effect on variable $\mathrm{Y}$, which is Academic Commercialization Capability.

\begin{tabular}{|c|c|c|c|c|c|c|}
\hline \multicolumn{7}{|c|}{ Coefficients $^{a}$} \\
\hline \multirow{2}{*}{\multicolumn{2}{|c|}{ Model }} & \multicolumn{2}{|c|}{ Unstandardized Coefficients } & $\begin{array}{c}\text { Standardized } \\
\text { Coefficients }\end{array}$ & \multirow[b]{2}{*}{$\mathrm{t}$} & \multirow[b]{2}{*}{ Sig. } \\
\hline & & $\mathrm{B}$ & Std. Error & Beta & & \\
\hline \multirow[t]{4}{*}{1} & (Constant) & 5.699 & 1.946 & & 2.928 & .004 \\
\hline & Strategic Leadership & -.412 & .169 & -.342 & -2.439 & .017 \\
\hline & Intrapreneurship orientation & 1.211 & .140 & 1.141 & 8.677 & .000 \\
\hline & University Support & -.100 & .081 & -.104 & -1.241 & .218 \\
\hline
\end{tabular}

a. Dependent Variable: Commercialization Capability

Based on the table above, it is obtained:

1. The regression coefficient value $-0,412<0$ with $t$ count $-2,439<\mathrm{t}$ table (1.96) and a significance of $0.017<0.05$. This shows that the Strategic Leadership variable has a negative and significant effect on the Commercialization Capability variable.

2. The regression coefficient value is $1.211>0$ with $\mathrm{t}$ count $8.677>\mathrm{t}$ table (1.96) and a significance of $0.000<0.05$. This shows that the Intrapreneurship Orientation variable has a positive and significant effect on the Commercialization Capability variable.

3. Regression coefficient value $-0,100<0$ with $t$ count $-1,241<\mathrm{t}$ table (1.96) and a significance of $0.218>0.05$. This shows that the University Support variable has a negative and insignificant effect on the Academic Commercialization Capability variable.

\section{DISCUSSION}

\subsection{Strategic Leadership on Academic Commercialization Capabilities}

The experience of writing research and publications is an important factor of Strategic Leadership that has an impact on entrepreneurial activities at a University. Commercialization Performance in academics emphasizes the role of a university leader. For example, it has been proven in numerous researches regarding the experience in scientific and leader's competency (Goodall 2006, 2009; Goodall et al., 2014).

\subsection{Intrapreneurship Orientation to Academic Commercialization Capabilities}

Researchers in search of truth must become entrepreneurs capable of adapting the knowledge to the necessities of external partners, taking into account the practical implications of the research (Eliaetal. 2017;
Etzkowitz, Viale 2010). The question is how colleges have learned about the transition in paradigm from scientific to technological institutions towards the paradigm shift from business universities, and how they can promote research groups. Research to coordinate their behavior in these new directions.

Universities, on the other hand, are no longer only research institutes. They must act as if they are "businesses," facilitating research into "markets" where "customers," such as financing agencies and private corporations, can purchase the results in exchange for grants. (Etzkowitz, 2003; Ziman, 1995).

By building theoretical models of academic business and deepening linkages between the experiences of various forms of academic leadership in activities we add to the literature.

\subsection{Intrapreneurship Orientation to Academic Commercialization Capabilities}

Truth seekers must become entrepreneurs who can consider the true meaning of research and adapt knowledge to the needs of external partners (Eliaetal, 2017; Etzkowitz and Viale, 2010). The question is what is the method of the universities to leverage this paradigm changes from scientific institutions to corporate universities, and how research groups can be facilitated to adapt to these new directions. But today, universities are more than just research institutes. They need to behave like "corporations" and place their studies in "markets" where "clients" such as funding agencies and private companies can purchase these results in exchange for cash funds (Etzkowitz, 2003; Ziman, 1995).

We constructing theoretical models of academic business and performing substantial research on the linkages between the experiences of various types of academic leaders in academic activities, we contribute to the academic. This will provide a better understanding of the mechanisms behind college entrepreneurship and help decision makers develop the 
right environment to encourage college entrepreneurship. As a result, their members often have to work with industrial and government partners to jointly develop and market new knowledge (Elia et al. 2017). Academic participation is defined as the collaboration of academic researchers with nonacademic entities on academic knowledge, including commissioned research, counseling, and informal activities. Above all, networks are less complicated than advice. Likewise, commercialization primarily involves the use of scholarly discoveries and the acquisition of economic benefits by establishing patents, licenses or scholarly spinoffs (Perkmann et al. 2013).

\section{AUTHORS' CONTRIBUTIONS}

This research is very useful for improving the competence of researchers careers as lecturers at the University of North Sumatra. And it is also hoped that the results of this research will be useful for Academicians, Research Institutions and Stakeholders.

\section{ACKNOWLEDGMENTS}

The researcher would like to thank the University of North Sumatra, especially the Rector and the Research Institute for the opportunity and support to conduct research through the 2020 Hibah TALENTA funding.

\section{REFERENCES}

[1]. Antončič, B. \& Hisrich, R.D. (2003). Clarifying the Intrapreneurship concept. Journal of Small Business and Enterprise Development 10(1), 7-24. https://doi.org/10.1108/ 02621710410541114

[2]. Blundell, R. \& Lockett, N. 2011, Exploring entrepreneurship: Practices and perspectives, Oxford University Press, New York, NY

[3]. Bolton, D.L. \& Lane, M.D., 2012, 'Individual entrepreneurial orientation: Development of a measurement instrument', Education + Training 54(2/3), 219-233.

[4]. Coulthard, C. \& Loos, J., 2007, Networking the missing link in firm based entrepreneurial orientation performance models, Working Paper Series, 1327-5216, Monash University, Department of Management, Melbourne.

[5]. Elia G, Secundo G, Passiante G (2017) Pathways towards the entrepreneurial university for creating entrepreneurial engineers: an Italian case. IJEIM 21:27-48. https://doi.org/10.1504/IJEIM.2017.10002349

[6]. Elia G, Secundo G, Passiante G (2017) Pathways towards the entrepreneurial university for creating entrepreneurial engineers: an Italian case. IJEIM
$21: 27-48$

https://doi.org/10.1504/IJEIM.2017.10002349

[7]. Etzkowitz H (2003) Research groups as 'quasifirms': the invention of the entrepreneurial university. Res Policy. https://doi.org/10.1016/S0048-7333(02)00009-4

[8]. Etzkowitz H (2016) The entrepreneurial university:Vision and metrics. Industry Higher Educ30:8397.https://doi.org/10.5367/ihe.2016.033

[9]. Goodall AH (2006) Should top universities be led by top researchers and are they? J Doc 62:388411. https://doi.org/10.1108/00220410610666529

[10]. Goodall AH, McDowell JM, Singell Jr. LD (2014) Leadership and the research productivity of university departments. https://ssrn.com/abstract=2385160. Accessed 6 Dec 2017

[11]. Ireland, R., \& Hitt, M. (1999). Achieving and Maintaining Strategic Competitiveness in the 21st century: the role of Kepemimpinan Strategis. Academy of Managerial Executive, 19.

[12]. Nyström, K., 2012, Entrepreneurial employees: Are they different from independent entrepreneurs?, Working Paper Series in Economics and Institutions of Innovation 281, Royal Institute of Technology, CESIS - Centre of Excellence for Science and Innovation Studies, viewed 12 January 2018, from https://static.sys.kth.se/itm/wp/cesis/cesiswp281.pd f.

[13]. Perkmann M, Tartari V, McKelvey M, Autio E, Broström A, D’Este P, Fini R, Geuna A, Grimaldi R, Hughes A, Krabel S, Kitson M, Llerena P, Lissoni F, Salter A, Sobrero M (2013) Academic engagement and commercialisation: a review of the literature on university-industry relations. Res Policy 42:423-442. https://doi.org/10.1016/j.respol.2012.09.007

[14]. Pinchot, G., 1985, Intrapreneuring, Harper \& Row, New York.

[15]. Rowe, W. (2001). Creating Wealth in Organizations: The role of Kepemimpinan Strategis. The Academy of Management Executive, 81.

[16]. Slaughter S, Leslie LL (2001) Expanding and elaborating the concept of academic capitalism. Organization 8:154-161. https://doi.org/10.1177/1350508401082003

[17]. Tijssen RJW (2006) Universities and industrially relevant science: towards measurement models and 
indicators of entrepreneurial orientation. Res Policy 35:1569-1585. https://doi.org/10.1016/j.respol.2006.09.025

[18]. Ziman J (1995) Prometheus Bound: Science in a dynamic steady state. In: Johnston R (ed) Prometheus Bound: Science in a dynamic steady state by John Ziman. Cambridge University Press, Cambridge, p ix +289 